OPEN ACCESS

Edited by:

Silke Salavati,

University of Edinburgh,

United Kingdom

Reviewed by:

Fabio Leonardi,

University of Parma, Italy

Meinoshin Okumura,

Toneyama National Hospital

(NHO), Japan

${ }^{*}$ Correspondence:

Sina Rehbein

sina.rehbein@fu-berlin.de

Specialty section:

This article was submitted to Comparative and Clinical Medicine,

a section of the journal

Frontiers in Veterinary Science

Received: 10 June 2019 Accepted: 07 August 2019

Published: 22 August 2019

Citation:

Rehbein S, Manchi G, Gruber AD and Kohn B (2019) Successful Treatment of Pneumothorax in a Dog With Sterile

Pleural Fibrosis Caused by

Chylothorax. Front. Vet. Sci. 6:278. doi: 10.3389/fvets.2019.00278

\section{Successful Treatment of Pneumothorax in a Dog With Sterile Pleural Fibrosis Caused by Chylothorax}

\author{
Sina Rehbein ${ }^{1 *}$, George Manchi ${ }^{1}$, Achim D. Gruber ${ }^{2}$ and Barbara Kohn ${ }^{1}$ \\ ${ }^{1}$ Clinic for Small Animals, Freie Universität, Berlin, Germany, ${ }^{2}$ Department of Veterinary Medicine, Institute of Veterinary \\ Pathology, Freie Universität, Berlin, Germany
}

A 2-year-old, $12 \mathrm{~kg}$, intact male crossbreed dog was presented with respiratory distress, exercise intolerance, and gagging. Plain thoracic radiographs revealed severe pleural effusion. Although bilateral needle thoracocentesis and chest tube placement were performed, no re-expansion of the lung lobes occurred. Pleural effusion was of chylous quality and led to lung entrapment. Computer tomography revealed a highly atrophic and atelectatic right middle lung lobe. The remaining lung lobes were only expanded to $\sim 40 \%$. Visceral pleura and pericardium showed a heterogeneous thickening consistent with pleural fibrosis. Partial pericardiectomy with resection of the middle lung lobe through a right lateral thoracotomy was performed. Ligation of the thoracic duct and ablation of the cisterna chyli was achieved through a single paracostal approach. Histopathology revealed chronic-active proliferative beginning granulomatous pleuritis, fibrotic pericarditis, and partial coagulative necrosis with incomplete granulomatous sequestration in the resected middle lung lobe. Chylothorax resolved after surgical intervention. Active pleural effusion resolved, and lung entrapment changed to trapped lung disease. The remaining lung lobes re-expanded to 80\% over the following 6 days. The dog was discharged 10 days later. Mild to moderate pleural effusion of non-chylic quality was present during the following 4 months. Meloxicam was administered for 4 months because of its anti-fibrotic and anti-inflammatory properties. Fifteen months later, thoracic radiographs revealed full radiologic expansion of the lungs with persistent mild pleural fibrosis. To the authors' knowledge, this is the first case report of pneumothorax due pleural fibrosis caused by chylothorax in a dog with an excellent clinical outcome.

Keywords: chylothorax, canine, pleural fibrosis, unexpandable lung, pneumothorax ex vacuo, NSAID, meloxicam

\section{BACKGROUND}

Pleural fibrosis is a rarely described pathological condition in dogs and cats. To the authors' knowledge, only 5 canine and 22 feline cases have been reported (Table 1). Previously, this condition was termed constrictive pleuritis. Due to pleural inflammation, a progressive constriction of lung parenchyma occurs, called lung entrapment. This condition may result in severe respiratory distress (6). In general, pleural fibrosis results from inflammatory processes within 
the thoracic cavity combined with active pleural effusions. Chylothorax and hemothorax are described in dogs with pleural fibrosis (Table 1). Radiologically, pleural fibrosis should be suggested if the lungs appears rounded accompanied with pleural effusion or if pneumothorax occurs after thoracocentesis (9). Decortication is recommended in case of severe respiratory distress. Complications like pneumothorax, tracheal tears, reexpansion pulmonary edemas, or death may occur $(5,7,10)$. Anti-inflammatory doses of prednisone were given in cats with severe pleural fibrosis. The results were variable (6). However, prognosis in dogs and cats with pleural fibrosis is poor. In the literature, mortality rate in dogs and cats amounts 70\% (17/24 dogs and cats with known outcome; Table 1).

The aim of this case report is to describe clinical presentation, imaging alterations, treatment and outcome in a dog with pneumothorax caused by pleural fibrosis after chylothorax.

\section{CASE PRESENTATION}

A 2-year-old, weighing $12 \mathrm{~kg}$, intact male crossbreed dog was referred to the Small Animal Clinic at Freie Universität Berlin with respiratory distress over the past 5 days. The owners observed a reduced appetite, exercise intolerance and gagging 2 weeks prior to admission. Pre-treatment with amoxicillin/clavulanic acid (20 mg/kg q12h PO) for 3 days was initiated by the referring veterinarian, but no clinical improvement occurred.

On presentation, the dog showed moderate tachypnea with a resting respiratory rate of 60 breaths per minute. Thoracic auscultation revealed muffled heart and significantly reduced lung sounds in the ventral thorax. On both thoracic sides, percussion produced a dampened, hyporesonant sound. All other clinical parameters were unremarkable. Hematology and blood chemistry were unremarkable with the exception of mild leukocytosis $\left(19.2^{*} 10^{9} / \mathrm{L}\right.$, reference interval [RI] 5.6-14.0* $\left.10^{9} / \mathrm{L}\right)$ and thrombocytosis $\left(456^{*} 10^{9} / \mathrm{L}, \mathrm{RI} 165-400^{*} 10^{9} / \mathrm{L}\right)$.

Stabilization was initialized with oxygen supplementation by mask with a flow rate of $2 \mathrm{~L} / \mathrm{min}$. Pulse oximetry revealed a $\mathrm{SpO}_{2}$ of $80 \%$. The dog was sedated with butorphanol (Butorgesic, cp-pharma ${ }^{\circledR}, 0.3 \mathrm{mg} / \mathrm{kg} \mathrm{IV)}$ and midazolam (Midazolam-ratiopharm ${ }^{\circledR}, 15 \mathrm{mg} / 3 \mathrm{ml}, 0.2 \mathrm{mg} / \mathrm{kg} \mathrm{IV}$ ). After initial stabilization, a left sided thoracic radiograph revealed severe pleural effusion (Figure 1A).

$750 \mathrm{ml}$ on the left and $600 \mathrm{ml}$ on the right thoracic side of a white-milky fluid was aspirated by needle thoracocentesis with a closed device under ultrasound guidance. Suction was performed until a negative pressure was obtained. A balanced crystalloid infusion (Sterofundin, B. Braun Melsungen AG; 2 $\mathrm{ml} / \mathrm{kg} / \mathrm{h} \mathrm{IV}$ ) and further oxygen supplementation were given. Clinical status improved. Breathing changed to a costoabdominal pattern with 32 breaths per minute and pulse oximetry revealed a $\mathrm{SpO}_{2}$ of $90 \%$. A second thoracic radiograph was made. All lung lobes appeared rounded with severely reduced volume and were

Abbreviations: DLH, domestic long hair; DSH, domestic short hair; IV, intravenous; N.a., not approved; PO, per os; RI, reference interval; SC, subcutaneous. collapsed and retracted from the parietal pleura. Marked pleural thickening of all lung lobes was present (Figures 1B,C). Pleural fibrosis was suggested (9).

Because the lung lobes did not re-expand after thoracocentesis, iatrogenic pneumothorax was suspected. Therefore, a second needle thoracocentesis on the left side was performed. Negative pressure was still present. As a next step, chest tubes with non-return valves (Heimlich type, LEO-ventil, Eickemeyer) were placed bilaterally under general anesthesia (induction with propofol (Narcofol, $10 \mathrm{mg} / \mathrm{ml}, \mathrm{cp}$-pharma ${ }^{\circledR}$ ); maintenance with isoflurane (Isofluran cp, cp-pharma ${ }^{\circledR}$ ); constant rate infusion with fentanyl (Fentadon ${ }^{\circledR}, 50 \mu \mathrm{g} / \mathrm{ml}$, Dechra, $0.01 \mathrm{mg} / \mathrm{kg} / \mathrm{h}$ ). During this intervention intermittent positive pressure ventilation was performed. Chest tubes were checked for possible leakage by active suction q24h and thoracic radiographs.

Effusion was diagnosed as exudative chylothorax [cholesterol effusion: $0.89 \mathrm{mmol} / \mathrm{L}$, cholesterol serum content $3.43 \mathrm{mmol} / \mathrm{L}$; triglycerides effusion: $6.51 \mathrm{mmol} / \mathrm{L}$, triglycerides serum content $0.53 \mathrm{mmol} / \mathrm{L}$; cholesterol: triglyceride ratio 0.14 $(<1)]$. Aerobic and anaerobic bacterial cultures were negative. Differential cell count showed a neutrophilia $\left(16.3^{*} 10^{9} / \mathrm{L}\right.$; RI $\left.3.6-12.0^{*} 10^{9} / \mathrm{L}\right)$, a monocytosis $\left(2.3^{*} 10^{9} / \mathrm{L}\right.$, RI $0.0-$ $\left.1.5^{*} 10^{9} / \mathrm{L}\right)$, and a lymphopenia $\left(0.38^{*} 10^{9} / \mathrm{L}\right.$, RI $\left.0.7-4.8^{*} 10^{9} / \mathrm{L}\right)$. Laboratory results were consistent with the presence of chylothorax and chronic inflammation. Abdominal radiographs and echocardiography were unremarkable. Despite clinical improvement at day three, there was no re-expansion of the lung lobes (Figures 1D,E). Computer tomography was performed under general anesthesia (premedication: $0.2 \mathrm{mg} / \mathrm{kg}$ midazolam (Midazolam-ratiopharm ${ }^{\circledR}, 15 \mathrm{mg} / 3 \mathrm{ml}$ ), combination product of $0.25 \mathrm{mg} / \mathrm{kg}$ levomethadonhydrochloride and $0.013 \mathrm{mg} / \mathrm{kg}$ fenpipramidhydhrochloride (L-Polamivet ${ }^{\circledR} \quad 2.5 / 0.125 \mathrm{mg} / \mathrm{ml}$, MSD); induction: $4 \mathrm{mg} / \mathrm{kg}$ propofol IV (Narcofol, $10 \mathrm{mg} / \mathrm{ml}, \mathrm{cp}-$ pharma ${ }^{\circledR}$; maintenance: isoflurane (Isofluran cp, cp-pharma ${ }^{\circledR}$ ). The dog was ventilated with intermittent positive pressure.

Computer tomographic examination revealed a heterogeneous pleural thickening of multiple lung lobes suggestive of pleural fibrosis. The right middle lung lobe was severely atrophic and atelectatic. The remaining lung lobes were only expanded to $40 \%$ on the right side. Left lung lobes were inflated up to $80 \%$. Mild pleural effusion (right $>$ left) was present (Figures 2A,B). Findings were consistent with hydropneumothorax. Contrast-enhanced computer tomography was unremarkable. Lymphangiography of the thoracic duct showed no extravasation of contrast medium.

After imaging, right lateral thoracotomy and a single paracostal approach was performed. To maintain analgesia, fentanyl (Fentadon ${ }^{\circledR}, 50 \mu \mathrm{g} / \mathrm{ml}$, Dechra) was given as a constant rate infusion $(0.01 \mathrm{mg} / \mathrm{kg} / \mathrm{h})$. Presurgical antibiotics were given (Amox/Clav HEXAL ${ }^{\circledR}$ i.v. 500/100 mg; $12.5 \mathrm{mg} / \mathrm{kg} \mathrm{IV)}$ and redosed after $90 \mathrm{~min}$. Pleural fibrosis presented as withish-tan material overlaying the lung lobes, preventing their re-expansion. Thoracic duct ligation, ablation of the chylic cisterna and a subtotal pericardiectomy were carried out. Due to its highly abnormal appearance, the middle lung lobe was resected. Both thoracic sides communicated well, thus only the left chest tube 
TABLE 1 | Summary of current literature about fibrosing pleuritis in dogs and cats.

\begin{tabular}{|c|c|c|c|c|c|c|c|}
\hline References & $\begin{array}{l}\text { Number of } \\
\text { patients }\end{array}$ & Species & Signalment & $\begin{array}{l}\text { Duration of } \\
\text { clinical signs }\end{array}$ & Diagnosis & Treatment & Outcome \\
\hline $\begin{array}{l}\text { Stevenson } \\
\text { et al. (1) }\end{array}$ & One & Cat & $\begin{array}{l}\text { 2-year-old, male DSH } \\
\text { cat }\end{array}$ & 4 weeks & Feline infectious peritonitis & N.a. & Cat died \\
\hline $\begin{array}{l}\text { Chastain } \\
\text { et al. (2) }\end{array}$ & One & Dog & $\begin{array}{l}\text { 5-year-old, male } \\
\text { Labrador Retriever }\end{array}$ & Unclear & $\begin{array}{l}\text { Granulomatous pleuritis, pericardial } \\
\text { effusion: Pasteurella multocida; } 8 \\
\text { months later pleural effusion: } \\
\text { Actinomyces bovis }\end{array}$ & $\begin{array}{l}\text { Pericardiocentesis, antibiotics; } 8 \text { months later: } \\
\text { thoracocentesis; euthanasia }\end{array}$ & Euthanasia \\
\hline Read (3) & One & Dog & $\begin{array}{l}\text { 4-year-old, male } \\
\text { Labrador }\end{array}$ & 1 day & $\begin{array}{l}\text { Traumatic hemothorax, constrictive } \\
\text { pleuritis, prednisone }\end{array}$ & Decortication & $\begin{array}{l}\text { Successful outcome; dog } 8 \text { months } \\
\text { later clinically unremarkable }\end{array}$ \\
\hline Glennon et al. (4) & ) One & Cat & $\begin{array}{l}\text { 18-year-old, castrated } \\
\text { male American } \\
\text { short-hair }\end{array}$ & Unclear & $\begin{array}{l}\text { Hyperthyroidism, chylothorax, } \\
\text { constrictive pleuritis }\end{array}$ & Thoracotomy, decortication & Euthanasia 5 days after surgery \\
\hline \multirow[t]{7}{*}{ Fossum et al. (5) } & Five & Dog & $\begin{array}{l}\text { 2-year-old, sexually } \\
\text { intact mixed-breed dog }\end{array}$ & 6 months & $\begin{array}{l}\text { Chylothorax, pleural fibrosis, Serratia } \\
\text { spp. }\end{array}$ & $\begin{array}{l}\text { Antibiotic therapy on the basis of sensitivity } \\
\text { testing }\end{array}$ & Dog died 3 days after admission \\
\hline & & Dog & $\begin{array}{l}\text { 3-year-old, sexually } \\
\text { intact male Shetland } \\
\text { Sheepdog }\end{array}$ & 4 days & Chylothorax, fibrosing pleuritis & $\begin{array}{l}\text { Surgical exploration euthanasia due to } \\
\text { guarded prognosis }\end{array}$ & Euthanasia \\
\hline & & Cat & $\begin{array}{l}\text { 5-year-old, neutered } \\
\text { male Himalayan cat }\end{array}$ & 18 months & Chylothorax, fibrosing pleuritis & $\begin{array}{l}\text { Antibiotics, needle thoracocentesis, surgical } \\
\text { exploration euthanasia due to guarded } \\
\text { prognosis }\end{array}$ & Euthanasia \\
\hline & & Cat & $\begin{array}{l}\text { 5-year-old, neutered } \\
\text { male DSH cat }\end{array}$ & 3 weeks & Chylothorax, fibrosing pleuritis & Euthanasia & Euthanasia \\
\hline & & Cat & $\begin{array}{l}\text { 4-year-old, spayed } \\
\text { DSH cat }\end{array}$ & 2 weeks & $\begin{array}{l}\text { FeLV positive, lymphoblastic } \\
\text { lymphosarcoma, fibrosing pleuritis }\end{array}$ & $\begin{array}{l}\text { Chemotherapy, needle thoracocentesis, } \\
\text { bilateral placement of perforated plastic } \\
\text { sheetings in the diaphragm }\end{array}$ & Euthanasia 4.5 months after surgery \\
\hline & & Cat & $\begin{array}{l}\text { 3-year-old, spayed } \\
\text { DSH cat }\end{array}$ & $\begin{array}{l}8 \text { months } \\
\text { chylothorax, } 3 \\
\text { weeks dyspnea } \\
\text { and lethargy }\end{array}$ & Chylothorax, fibrosing pleuritis & $\begin{array}{l}\text { Needle thoracocentesis, surgical exploration, } \\
\text { bilateral placement of perforated plastic } \\
\text { sheetings }\end{array}$ & Cat died $72 \mathrm{~h}$ after surgery \\
\hline & & Cat & $\begin{array}{l}\text { 5-year-old, neutered } \\
\text { male DSH cat }\end{array}$ & 9 months & Chylothorax, fibrosing pleuritis & $\begin{array}{l}\text { Surgical exploration, decortication, partial } \\
\text { lobectomy, chest tube placement, pulmonary } \\
\text { edema }\end{array}$ & Cat died $4 \mathrm{~h}$ after surgery \\
\hline \multirow[t]{4}{*}{ Suess et al. (6) } & $\begin{array}{l}\text { Ten [one cat } \\
\text { published in } \\
\text { Glennon et al. } \\
\text { (4)] }\end{array}$ & Cat & $\begin{array}{l}\text { 12-year-old, male } \\
\text { castrated DSH cat }\end{array}$ & 1 week & Chylothorax, HCM, fibrosing pleuritis & Captopril, furosemide, acetylsalicylic acid & $\begin{array}{l}\text { Euthanasia } 12 \text { weeks after initial } \\
\text { presentation }\end{array}$ \\
\hline & & Cat & $\begin{array}{l}\text { 8-year-old, female } \\
\text { spayed DSH cat }\end{array}$ & 13 weeks & Chylothorax, fibrosing pleuritis & $\begin{array}{l}\text { Periodic thoracocentesis, low-fat diet, } \\
\text { exercise restriction }\end{array}$ & $\begin{array}{l}\text { Euthanasia } 52 \text { weeks after initial } \\
\text { presentation }\end{array}$ \\
\hline & & Cat & $\begin{array}{l}\text { 7-year-old, male } \\
\text { castrated Himalayan }\end{array}$ & 4 weeks & Chylothorax, fibrosing pleuritis & Thoracic duct ligation & $\begin{array}{l}\text { Resolution of chylothorax; } \\
\text { non-chylous effusion; cat died } 16 \\
\text { weeks after initial presentation }\end{array}$ \\
\hline & & Cat & $\begin{array}{l}\text { 4-year-old, male } \\
\text { castrated DSH cat }\end{array}$ & 3 weeks & Chylothorax, fibrosing pleuritis & Thoracic duct ligation, prednisone & $\begin{array}{l}\text { Resolution of chylothorax; alive } 82 \\
\text { weeks after initial presentation }\end{array}$ \\
\hline
\end{tabular}


TABLE 1 | Continued

\begin{tabular}{|c|c|c|c|c|c|c|c|}
\hline References & $\begin{array}{l}\text { Number of } \\
\text { patients }\end{array}$ & Species & Signalment & $\begin{array}{l}\text { Duration of } \\
\text { clinical signs }\end{array}$ & Diagnosis & Treatment & Outcome \\
\hline & & Cat & $\begin{array}{l}\text { 3-year-old, male } \\
\text { castrated Himalayan }\end{array}$ & 30 weeks & Chylothorax, fibrosing pleuritis & Prednisone & $\begin{array}{l}\text { Resolution of chylothorax; alive } 69 \\
\text { weeks after initial presentation }\end{array}$ \\
\hline & & Cat & $\begin{array}{l}\text { 5-year-old, female } \\
\text { spayed DSH }\end{array}$ & 17 weeks & Chylothorax, fibrosing pleuritis & $\begin{array}{l}\text { Periodic thoracocentesis, low-fat diet, } \\
\text { exercise restriction }\end{array}$ & $\begin{array}{l}\text { Euthanasia } 2 \text { days after initial } \\
\text { presentation }\end{array}$ \\
\hline & & Cat & $\begin{array}{l}\text { 7-year-old, male } \\
\text { castrated DLH cat }\end{array}$ & 5 weeks & Chylothorax, fibrosing pleuritis & Thoracic duct ligation, prednisone & $\begin{array}{l}\text { Resolution of chylothorax; } \\
\text { non-chylous effusion; euthanasia } 8 \\
\text { weeks after initial presentation }\end{array}$ \\
\hline & & Cat & $\begin{array}{l}\text { 4-year-old, male } \\
\text { castrated DSH }\end{array}$ & 9 weeks & Chylothorax, fibrosing pleuritis & Thoracic duct ligation, prednisone & $\begin{array}{l}\text { Resolution of chylothorax: } \\
\text { non-chylous effusion; euthanasia } 30 \\
\text { weeks after initial presentation }\end{array}$ \\
\hline & & Cat & $\begin{array}{l}\text { 12-year-old, female } \\
\text { spayed DSH cat }\end{array}$ & 1 day & Chylothorax, fibrosing pleuritis & $\begin{array}{l}\text { Thoracic duct ligation, prednisone, passive } \\
\text { peritoneal lavage }\end{array}$ & $\begin{array}{l}\text { Resolution of chylothorax; } \\
\text { non-chylous effusion; euthanasia } 3 \\
\text { weeks after initial presentation }\end{array}$ \\
\hline \multirow[t]{3}{*}{ Fossum et al. (7) } & Three & Cat & N.a. & 2 weeks to 1 year & Chylothorax, severe fibrosing pleuritis & $\begin{array}{l}\text { Thoracotomy with thoracic duct ligation, } \\
\text { pericardiectomy, two cats received } \\
\text { decortication, complications: two cats had } \\
\text { pneumothorax, one cat had tracheal tear }\end{array}$ & $\begin{array}{l}\text { Pneumothorax resolved in both cats } \\
\text { with decortication; remaining cats } \\
\text { unclear }\end{array}$ \\
\hline & Two & Cat & N.a. & 2 weeks to 1 year & $\begin{array}{l}\text { Chylothorax, moderate fibrosing } \\
\text { pleuritis }\end{array}$ & & \\
\hline & One & Dog & N.a. & 2 weeks to 1 year & Chylothorax, mild fibrosing pleuritis & $\begin{array}{l}\text { Thoracotomy with thoracic duct ligation, } \\
\text { pericardiectomy }\end{array}$ & Chylothorax resolved \\
\hline Lafond et al. (8) & One & Cat & $\begin{array}{l}\text { 6-year-old, spayed } \\
\text { female Himalayan cat }\end{array}$ & 2 months & Chylothorax, constrictive pleuritis & $\begin{array}{l}\text { Omentalization of the thorax, partial } \\
\text { decortication; complication: transient } \\
\text { pneumothorax }\end{array}$ & $\begin{array}{l}\text { Full recovery; clinically normal } 13 \\
\text { months after surgery }\end{array}$ \\
\hline
\end{tabular}

N.a., not approved; DSH, domestic shorthair; $D L H$, domestic longhair. 


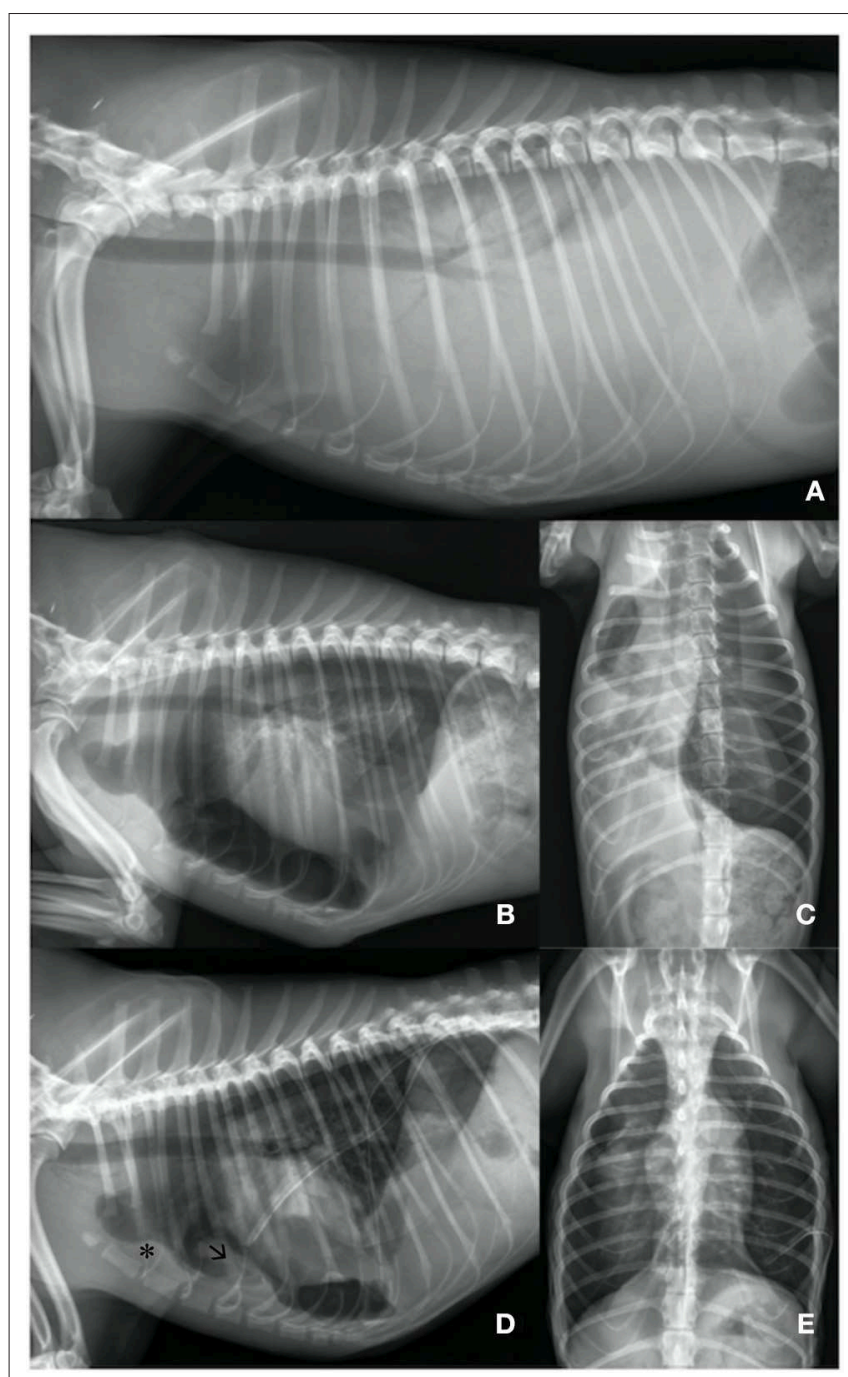

FIGURE 1 | (A) Day 1: Lateral left sided thoracic radiograph view: Markedly increased soft- tissue opacity with completely silhouetted cardiac silhouette and retracted lung lobes due to a severe pleural effusion. $(\mathbf{B}, \mathbf{C})$ Day 1 : Lateral left sided and ventrodorsal thoracic radiograph view: After needle thoracocentesis lung lobes were severely rounded and expanded to $\sim 40 \%$. Heterogenous pleural thickening is present. The heart is detached from the sternum. An iatrogenic pneumothorax was suspected. (D,E) Day 3: Lateral left sided and ventrodorsal thoracic radiograph view: Chest tubes are placed bilaterally. Lung lobes are re-expanded to $80 \%$ on the left and to $60 \%$ on the right side. Sternal lymphnode (asterisk) is prominent and a precardial mass-effect (arrow) is seen. The latter is suggestive for fibrotic tissue.

with a non-return valve (Heimlich type, LEO-ventil, Eickemeyer) was left. Chest tube functionality was assessed clinically, by measurement of produced fluid, active suction $\mathrm{q} 24 \mathrm{~h}$ and by thoracic radiographs (Figures 3A,B).

Bacterial culture of the resected middle lung lobe was negative. Histology revealed severe, chronic-active, proliferative, and beginning granulomatous pleuritis. Additionally, a moderate to severe subacute to chronic, purulent proliferative, and beginning fibrotic pericarditis with predominantly fibrotic deposits on the serosal lining was diagnosed. A sub-acute to chronic granulomatous, partially demarcated coagulative necrosis of the parenchyma of the middle lung lobe with partially massive and predominantly resorbed hemorrhages, thrombosed vessels, and micro-fragmented bronchi were detected. With periodic acidSchiff reaction no foreign material, fungal, or parasitic structures were detected (11). Ziehl-Neelsen staining was negative. These findings suggested that the sterile inflammatory process had occurred for at least several weeks, likely much longer. Idiopathic chylothorax with granulomatous pleuritis and highly atelectatic middle lung lobe was diagnosed.

Further patient management included a continuous rate infusion with balanced crystalloids and analgesics $(2 \mathrm{ml} / \mathrm{kg} / \mathrm{h}$ Sterofundin, B. Braun Melsungen AG, $0.002 \mathrm{mg} / \mathrm{kg} / \mathrm{h}$ fentanyl (Fentadon, $50 \mu \mathrm{g} / \mathrm{ml}, \quad$ Dechra), $0.12 \mathrm{mg} / \mathrm{kg} / \mathrm{h}$ ketamine (Anesketin, $100 \mathrm{mg} / \mathrm{ml}$, Dechra), and $0.2 \mathrm{mg} / \mathrm{kg} / \mathrm{h}$ lidocaine (LidoCARD, 2\%, B. Braun) for 2 days (12). During inpatient treatment the dog was clinically unremarkable. Starting at day three after thoracotomy meloxicam (Metacam, Boehringer Ingelheim; initially $0.2 \mathrm{mg} / \mathrm{kg} \mathrm{SC}$, q24h then $0.1 \mathrm{mg} / \mathrm{kg}, \mathrm{q} 24 \mathrm{~h}$ PO) was administered for 4 months. During this time no gastroprotective agents were given. Amoxicillin clavulanate (12.5 $\mathrm{mg} / \mathrm{kg} \mathrm{q} 12 \mathrm{~h}$ PO) was administered for 3 days until bacterial culture confirmed negativity. The dog tolerated meloxicam well and did not show any side effects.

Lungs re-expanded to $\sim 80 \% \quad 6$ days after surgery (Figures 3A,B). Ten days after thoracotomy, the remaining chest tube was removed. The dog was discharged $7 \mathrm{~h}$ after chest tube withdrawal with a normal breathing pattern and a SpO2 of $98 \%$. Clinical, radiographic and ultrasonographic follow-up examinations were performed every two to 14 days within the first two months. Further controls were carried out 2, 4, 6, and 15 months later. Pleural effusion persisted for 4 months (Figures 3C-H). Seven days postoperatively effusion specimen was generated from the chest tube. Effusion was diagnosed as non-chylic, non-septic, serosanguineous exudate (cell count: $16,146^{*} 10^{9} / \mathrm{L}$; protein content: $14 \mathrm{~g} / \mathrm{L}$; triglyceride effusion: $0.21 \mathrm{mmol} / \mathrm{L}$; triglyceride serum: $0.70 \mathrm{mmol} / \mathrm{L}$ ). On day 24 , modified transudate (cell count: $3,566^{*} 10^{9} / \mathrm{L}$; protein content: $28 \mathrm{~g} / \mathrm{L}$ ) and 3.5 months later transudate was present (cell count: $1,698^{*} 10^{9} / \mathrm{L}$; protein content: $13 \mathrm{~g} / \mathrm{L}$ ). Both effusion specimens were obtained by needle thoracocentesis. Lungs were inflated to $\sim 95 \% 4$ months after initial presentation. Fifteen months post initial presentation, complete re-expansion of the lungs was seen. Pleural effusion was evident neither on radiographs (Figures 3I,J) nor by ultrasonography. Mild pleural fibrosis persisted. Material of soft-tissue opacity overlaid the cardiac silhouette. Fine needle aspiration was performed, and fibrotic tissue was suggested. During the whole observation period the dog was clinically unremarkable. A telephone conversation with the owners 5 years later revealed that the dog is clinically healthy.

\section{DISCUSSION}

Pleural fibrosis develops when pleural effusions irritate the lungs' pleura. Fibrin formation is promoted by the release of chemokines and cytokines (e.g., TGF- $\beta$ and TNF- $\alpha$ ) (13-17). 


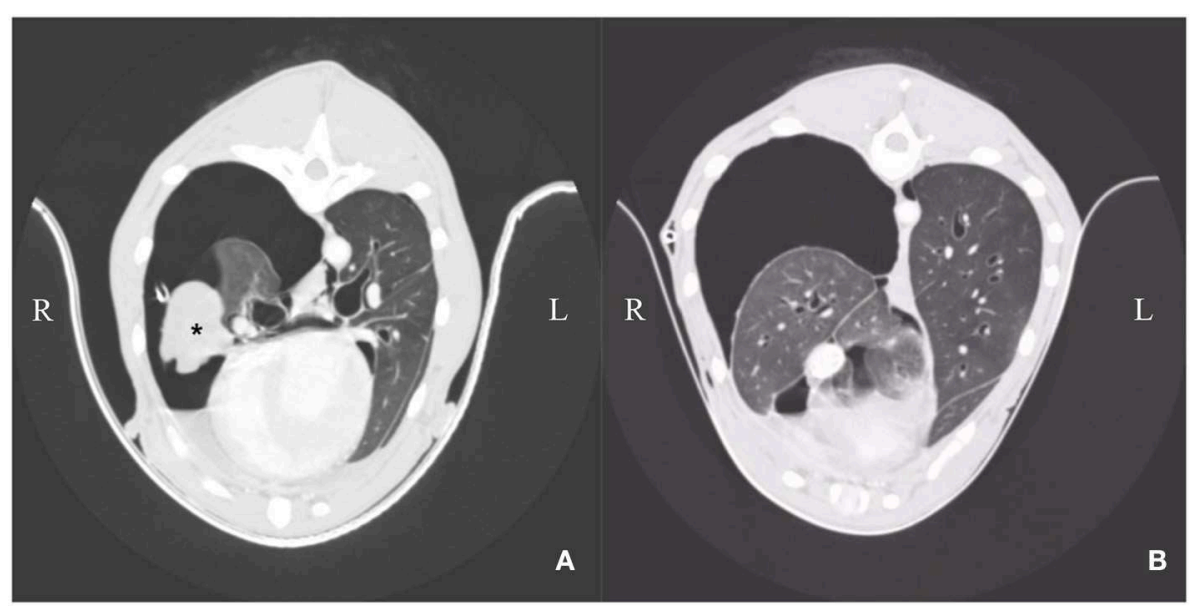

FIGURE 2 | (A,B) Day 3: Computer tomography: Heterogenous pleural thickening of multiple lung lobes is seen. The right middle lung lobe is severely atrophic and atelectatic (asterisk). The remaining lung lobes are expanded to $\sim 40 \%$ on the right side. Left lung lobes are nearly completely re-expanded on the left side. Mild pleural effusion is present (right $>$ left).

Although some aspects of pathophysiology are already known, it is still unclear why some patients develop pleural fibrosis and others do not (13).

Various causes of pleural fibrosis in dogs are described. One dog suffered from granulomatous pleuritis, which is a form of pleural fibrosis (18). Bacterial culture detected Pasteurella multocida within the pericardial effusion. Antibiotic therapy was introduced but 9 months later Actinomyces bovis was detected in the thoracic cavity. Due to guarded prognosis the animal was euthanized (2). Another dog with pleural fibrosis was infected with Serratia spp. after thoracocentesis. Despite adequate antibiotics, the dog died 2 days after initial presentation (5). Further known causes of pleural fibrosis in dogs are presence of chylothorax $(n=3)$ and traumatic hemothorax $(n=1)(3,5,7)$. In cats, chylothorax is the most common cause of pleural fibrosis ( $n=20$; Table 1$)$. One case each was described with feline infectious peritonitis and lymphoblastic lymphoma (FeLV positive) (Table 1). In the present case, pleural alterations hindered the lungs to completely re-expand and were caused by chylic effusion. Neither by bacterial culture nor by histopathological examination infectious agents were detected. Therefore, idiopathic chylothorax was diagnosed (9).

In general, pneumothorax can be classified in dogs as traumatic (e.g., dog bite), spontaneous (e.g., blebs or bullae), or iatrogenic (e.g., after thoracocentesis). Spontaneous pneumothorax is defined as a non-traumatic and closed pneumothorax. It can even occur after laparoscopic ovariectomy $(19,20)$. All these kinds of pneumothorax are characterized by the presence of supraatmospheric intrapleural pressure (19). In contrast, negative intrapleural pressure is seen in a state called pneumothorax ex vacuo, which is associated in human medicine with an entity called trapped lungs. This entity is one of two different types of unexpandable lungs. This condition occurs in patients with remote pleural inflammation due to infections, hemothorax, pneumothorax, uremia, rheumatoid pleurisy, or thoracic interventions. Negative intrapleural pressure hinders the lungs to re-expand. Effusion is of transudative quality. Patients are mostly asymptomatic. In contrast, lung entrapment is associated with an active pleural inflammation due to active pleural infections or malignant processes. Patients are presented with dyspnea and pleurisy. Intrapleural pressure can be positive and pleural effusions are exudative $(10,21)$. In human medicine, pleural manometry is recommended to estimate intrathoracic pressure and to distinguish between these two entities (22).

However, a clear distinction is difficult. One study proposed that lung entrapment leads to pleural fibrosis. Subsequently, trapped lung can develop, if the initial insult is resolved (21). It is likely that this occurred in our dog. Actively formed chylothorax led to lung entrapment, which resulted after successful surgery in trapped lung with passively formed transudate and pneumothorax ex vacuo. Manometry was not performed, because it was unavailable.

To what extent middle lung lobe atrophy and necrosis contributed to lung entrapment or trapped lung is questionable. Two scenarios are possible. First scenario is that alterations of the middle lung lobe resulted from lung lobe torsion as a consequence of severe pleural effusion or trauma (23). A second possibility is that middle lung lobe atelectasis resulted from increased pressure on lungs' parenchyma due to severe pleural effusion (24). Both options could not be proven by computer tomography or by pathohistological examination.

Patients suffering from pneumothorax ex vacuo may be mostly asymptomatic. This is consistent with our case and underlines the presence of trapped lung (10). In contrast, previously reported canine and feline cases described that patients suffered mostly from severe respiratory distress $(5,10,13)$. This would support the assumption that lung entrapment overweighed in these cases. However, a distinction between trapped lungs and lung entrapment was not done. 


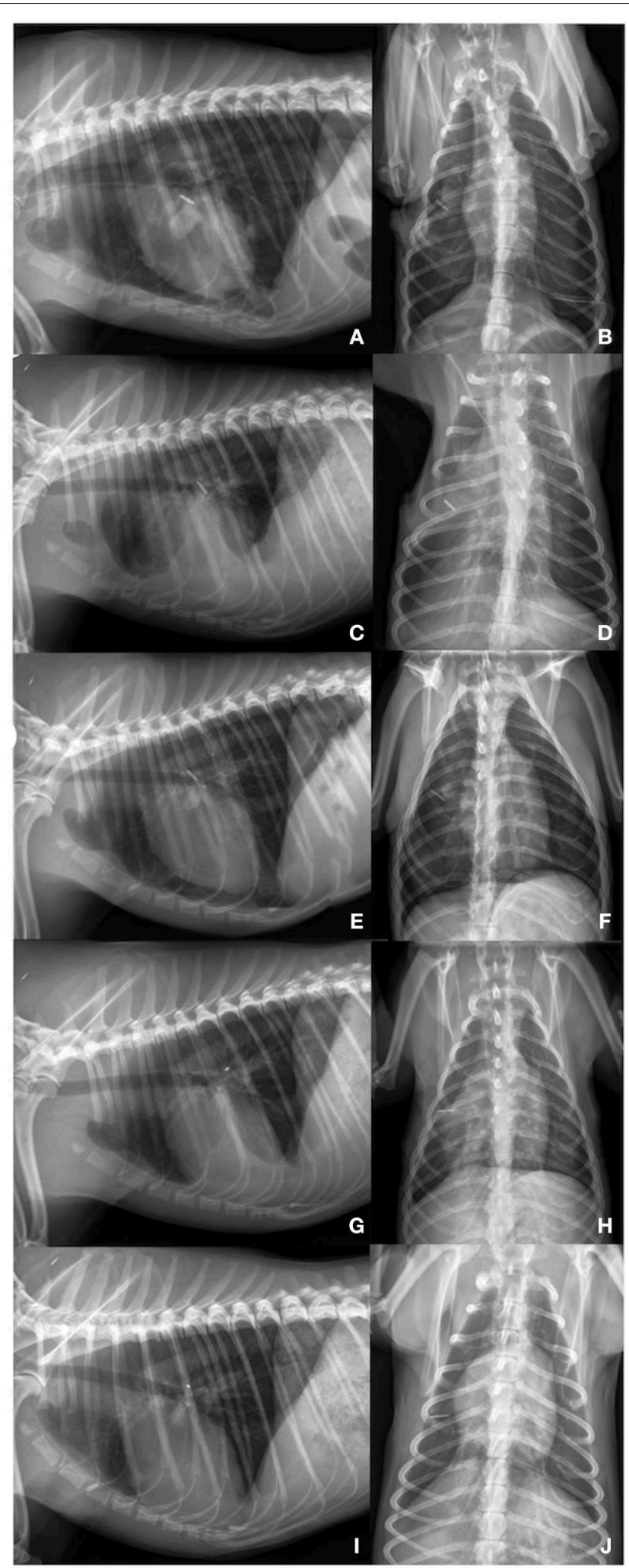

FIGURE 3 | (A,B) Day 6: Lateral left sided and ventrodorsal thoracic radiograph view: Lung lobes re-expanded to $80 \%$ on the left and right side.

(Continued)
FIGURE 3 | Titanum clips are present on the height of the right middle lung lobe. On the left side a chest tube is placed. Pleural thickening is present in all remaining lung lobes. Cardiac silhouette is slightly detached from the sternum. (C,D) Day 18: Lateral left sided and ventrodorsal thoracic radiograph view: Moderate increased soft- tissue opacity with partially silhouetted cardiac silhouette. Lung lobes are mildly retracted (90\% re-expansion). On the left side a chest tube is present. (E,F) Day 24: Lateral left sided and ventrodorsal thoracic radiograph view: After needle thoracocentesis: Lung lobes are expanded to $\sim 80 \%$ on the left and $70 \%$ on the right side. Heterogenous pleural thickening of the remaining lung lobes is seen. $\mathbf{( G , H )} 4$ months later: Lung lobes are re-expanded to 95\% on both thoracic sides. Mild pleural fibrosis is present. Mild fluid accumulation is seen. (I,J) 15 months later: Lateral left sided and ventrodorsal thoracic radiograph view: Complete re-expansion of all lung lobes. Mild pleural fibrosis is still present. Material of soft-tissue opacity is seen overlaying the cardiac silhouette. Fine needle aspiration revealed the presence of fibrotic tissue. Fluid accumulation could be excluded by ultrasonography.

The main goal should be to rule out underlying disease processes. Successful treatment hinders further irritations of the pleura and thus progression of fibrin formation (7, 25). As a standard, complete blood cell count, serum biochemistry, effusion analysis including measurements of triglycerides and cholesterol in comparison with serum values, cytology, aerobic and anaerobic culture, thoracic radiographs, and echocardiography should be performed (26). Radiological findings can be suggestive for pleural fibrosis. One study proposed, that two out of three following radiological findings should be present: first pleural thickening, second rounded lung lobes and/or third persistently retracted lung lobes (6). All these alterations were detectable in our dog. Computer tomography is helpful to outline the degree of pleural fibrosis, degree of lung's expansion, course and branching of the thoracic duct, or malignant processes (27). Intra operative presentation is also indicative for pleural fibrosis. Withish-tan material overlays the lungs with variable degrees of adhesion to other intra-thorax structures $(5,6)$. Despite the presence of fibrous peel surrounding the lungs' parenchyma, it was certainly advantageous for our patient's outcome that no further adhesions were present. To confirm a diagnosis and also to exclude possible underlying diseases, biopsies and pathohistological analysis should be carried out.

In patients with pneumothorax ex vacuo, chest tube placement is not appropriate, because this kind of pneumothorax results from a re-equilibration of intra- and extra-pulmonary pressure (10). Decortication is only recommended in humans and pets with severe respiratory distress, because clinical signs can be fatal. Pneumothorax, tracheal tears, hemorrhages, reexpansion pulmonary edemas, or death can occur $(5,7)$. Our patient benefited of chest tube placement, because further accumulation of chylic effusion and lung entrapment was reduced. Decortication was not performed, because clinical signs and intraoperative findings were not severe.

To inhibit further inflammation, glucocorticoids were given in cats with variable outcomes (6). In humans, these are only indicated and successful in rheumatoid pleurisy (13). No other inflammatory drugs are described in clinical patients. 
Experimental studies in mice and rats showed that the NSAID meloxicam had anti-fibrotic properties in kidneys, liver, lung, and pleurisy (28-31). Glucocorticoids were not given in our patient, because wound healing could be delayed, and risk of infection can be increased. Side-effects like polyuria, polydipsia, and panting can also be severe in some dogs. Therefore, meloxicam was given for 4 months until transudative effusion was seen. Pneumothorax ex vacuo resolved, but mild pleural fibrosis persisted. After withdrawal of meloxicam pleural effusion did not reoccurred. It is likely that meloxicam encouraged pleural remodeling and lung expansion, although complete resolution of pleural fibrosis was not achieved. However, NSAIDs should be used cautiously. Gastrointestinal signs like vomitus and diarrhea are the main side effects of the COX-1 sparing meloxicam. The incidence of adverse reactions is inconsistently described (32). Clinical signs were obvious in up to $25 \%$ of patients with varying treatment durations (1-84 days) and dosages (33-37). Thus, comparability of data is difficult. However, an increased duration of meloxicam administration is not necessarily associated with a higher incidence of side effects. Administration up to 84 days resulted in adverse effects in $3.4 \%$ of dogs, whereas a treatment duration of 28 days in another study caused side effects in $25 \%$ of dogs $(34,37)$. The longest duration of administration was reported in a safety study of transmucosal meloxicam application. Meloxicam was given 26 weeks with up to the fifths time of maximum proposed dosage. Gastrointestinal signs were mainly obvious at higher dosages (38). To ensure drug compatibility in our dog periodic clinical, hematology and blood biochemistry examinations were performed. Additionally, the owners were instructed to closely monitor the dog's behavior, appetite and feces. Currently, prophylactic administration of gastroprotective drugs was not proven to be beneficial, if NSAIDs were given (39). Our dog did not show any obvious side effects, thus, no gastroprotective agents were administered.

Prognosis in dogs and cats with pleural fibrosis is generally poor. In the veterinary literature a high mortality rate is reported. This contrasts with our patient, who had an excellent outcome. It is evident that further investigations are necessary to characterize canine lung trapping and entrapment lungs in detail. The effectiveness of meloxicam in canine granulomatous pleuritis should be ruled out in further clinical studies. However, results of this presented case are promising.

\section{REFERENCES}

1. Stevenson RG, Tilt SE, Purdy JG. Case report. Feline infectious peritonitis and pleurisy. Can Vet J. (1971) 12:97-9.

2. Chastain CB, Greve JH, Riedesel DH. Pericardial effusion from granulomatous pleuritis and pericarditis in a dog. J Am Vet Med Assoc. (1974) 164:1201-2.

3. Read AA. Successful treatment of organizing hemothorax by decortication in a dog: a case report. JAAHA. (1981) 17:167-75.

4. Glennon JC, Flanders JA, Rothwell JT, Shelly, S. Constrictive pleuritis with chylothorax in a cat: a case report. J Am Anim Hosp Assoc. (1987) 23:539-42.

5. Fossum TW, Evering WN, Miller MW, Forrester SD, Palmer DR, Hodges CC. Severe bilateral fibrosing pleuritis associated with chronic chylothorax in five cats and two dogs. J Am Vet Med Assoc. (1992) 201:317-24.

\section{CONCLUDING REMARKS}

To the authors' knowledge, this is the first case report with pneumothorax ex vacuo caused by sterile granulomatous pleuritis and chylothorax in a dog with an excellent clinical outcome.

Meloxicam seemed to encourage pleural remodeling and lung expansion, although complete resolution of pleural fibrosis was not achieved.

\section{DATA AVAILABILITY}

All datasets generated for this study are included in the manuscript.

\section{ETHICS STATEMENT}

The dog detailed in the case report was presented at the Small Animal Clinic at the Freie Universität Berlin because of severe dyspnea. The owners signed a consent form to permit the diagnostic procedure, treatment on the dog, and to use the collected clinical data.

\section{AUTHOR CONTRIBUTIONS}

SR contributed to writing the manuscript and review, undertook, additionally, the emergency and postoperatively treatment, and made the control examinations. GM and SR interpreted and described the imaging. GM was the primary surgeon and contributed to writing the manuscript. AG performed the pathohistological examination and contributed to writing the manuscript. BK contributed to dog's treatment and writing the manuscript.

\section{FUNDING}

We acknowledge support by the German Research Foundation and the Open Access Publication Fund of the Freie Universität Berlin.

6. Suess RP, Flanders JA, Beck KA, Earnest-Koons K. Constrictive pleuritis in cats with chylothorax: 10 cases (1983-1991). JAAHA. (1994) 30:70-7.

7. Fossum TW, Mertens MM, Miller MW, Peacock JT, Saunders A, Gordon S, et al. Thoracic duct ligation and pericardectomy for treatment of idiopathic chylothorax. J Vet Intern Med. (2004) 18:307-10. doi: 10.1111/j.1939-1676.2004.tb02550.x

8. Lafond E, Weirich WE, Salisbury SK. Omentalization of the thorax for treatment of idiopathic chylothorax with constrictive pleuritis in a cat. J Am Anim Hosp Assoc. (2002) 38:74-8. doi: 10.5326/0380074

9. Singh A, Brisson B, Nykamp S. Idiopathic chylothorax: pathophysiology, diagnosis, and thoracic duct imaging. Compend Contin Educ Vet. (2012) 34:E2.

10. Huggins JT, Maldonado F, Chopra A, Rahman N, Light, R. Unexpandable lung from pleural disease. Respirology. (2018) 23:160-7. doi: 10.1111/resp.13199 
11. Chandler FW. Infectious disease pathology: morphologic and molecular approaches to diagnosis. J Histotechnol. (1995) 18:183-6. doi: 10.1179/his.1995.18.3.183

12. Fossum TW. Perioperatives multimodales Schmerzmanagement. In: Chirurgie der Kleintiere. München: Elsevier GmbH, Urban \& Fisher Verlag. (2009). p. 145.

13. Huggins JT, Sahn SA. Causes and management of pleural fibrosis. Respirology. (2004) 9:441-7. doi: 10.1111/j.1440-1843.2004.00630.x

14. Grande JP. Role of transforming growth factor-beta in tissue injury and repair. Proc Soc Exp Biol Med. (1997) 214:27-40. doi: 10.3181/00379727-214-44066

15. Batra H, Antony VB. Pleural mesothelial cells in pleural and lung diseases. $J$ Thorac Dis. (2015) 7:964-80. doi: 10.3978/j.issn.2072-1439.2015.02.19

16. Yano S, Shinohara H, Herbst RS, Kuniyasu H, Bucana CD, Ellis LM, et al. Production of experimental malignant pleural effusions is dependent on invasion of the pleura and expression of vascular endothelial growth factor/vascular permeability factor by human lung cancer cells. Am J Pathol. (2000) 157:1893-903. doi: 10.1016/S0002-9440(10)64828-6

17. Decologne N, Kolb M, Margetts PJ, Menetrier F, Artur Y, Garrido C, et al. TGF-betal induces progressive pleural scarring and subpleural fibrosis. $J$ Immunol. (2007) 179:6043-51. doi: 10.4049/jimmunol.179.9.6043

18. Cagle PT, Allen TC. Pathology of the pleura: what the pulmonologists need to know. Respirology. (2011) 16:430-8. doi: 10.1111/j.1440-1843.2011.01957.x

19. Maritato KC, Colon JA, Kergosien DH. Pneumothorax. Compend Contin Educ Vet. (2009) 31:232-42; quiz 242.

20. Bendinelli C, Leonardi F, Properzi, R. Spontaneous pneumothorax in two dogs undergoing combined laparoscopic ovariectomy and total laparoscopic gastropexy. J Vet Sci. (2019) 20:e25. doi: 10.4142/jvs.2019.20.e25

21. Owen SC, Bersabe DR, Skabelund AJ, McCann ET, Morris MJ. Transudative chylothorax from cirrhosis complicated by lung entrapment. Respir Med Case Rep. (2016). doi: 10.1016/j.rmcr.2015.12.007. [Epub ahead of print].

22. Huggins JT, Doelken P. Pleural manometry. Clin Chest Med. (2006) 27:22940. doi: 10.1016/j.ccm.2005.12.007

23. Park KM, Grimes JA, Wallace ML, Sterman AA, Thieman Mankin KM, Campbell BG, et al. Lung lobe torsion in dogs: 52 cases (2005-2017). Vet Surg. (2018) 47:1002-8. doi: 10.1111/vsu.13108

24. Reed JC. Atelectasis. In: Chest Radiology. Philadelphia, PA: Elsevier (2019). p. 166-84.

25. Doelken P. Clinical implications of unexpandable lung due to pleural disease. Am J Med Sci. (2008) 335:21-5. doi: 10.1097/MAJ.0b013e31815f1a44

26. Epstein SE. Exudative pleural diseases in small animals. Vet Clin North Am Small Anim Pract. (2014) 44:161-80. doi: 10.1016/j.cvsm.2013.08.005

27. Lee N, Won S, Choi M, Kim J, Yi K, Chang D, et al. CT thoracic duct lymphography in cats by popliteal lymph node iohexol injection. Vet Radiol Ultrasound. (2012) 53:174-80. doi: 10.1111/j.1740-8261.2011.01892.x

28. Arafa HM, Abdel-Wahab MH, El-Shafeey MF, Badary OA, Hamada FM. Antifibrotic effect of meloxicam in a murine lung fibrosis model. Eur J Pharmacol. (2007) 564:181-9. doi: 10.1016/j.ejphar.2007.02.065

29. Hassan MH, Ghobara, M.M. Antifibrotic effect of meloxicam in rat liver: role of nuclear factor kappa B, proinflammatory cytokines, and oxidative stress. Naunyn Schmiedebergs Arch Pharmacol. (2016) 389:971-83. doi: 10.1007/s00210-016-1263-1

30. Edfawy M, Hassan MH, Mansour A, Hamed AA, Amin HA. Meloxicam modulates oxidative stress status, inhibits prostaglandin E2, and abrogates apoptosis in carbon tetrachloride-induced rat hepatic injury. Int J Toxicol. (2012) 31:276-86. doi: 10.1177/1091581812442939

31. Ianiski FR, Alves CB, Ferreira CF, Rech VC, Savegnago L, Wilhelm EA, et al. Meloxicam-loaded nanocapsules as an alternative to improve memory decline in an Alzheimer's disease model in mice: involvement of $\mathrm{Na}(+), \mathrm{K}(+)$ ATPase. Metab Brain Dis. (2016) 31:793-802. doi: 10.1007/s11011-016-9812-3

32. Monteiro-Steagall BP, Steagall PV, Lascelles BD. Systematic review of nonsteroidal anti-inflammatory drug-induced adverse effects in dogs. J Vet Intern Med. (2013) 27:1011-9. doi: 10.1111/jvim.12127

33. Moreau M, Dupuis J, Bonneau NH, Desnoyers M. Clinical evaluation of a nutraceutical, carprofen and meloxicam for the treatment of dogs with osteoarthritis. Vet Rec. (2003) 152:323-9. doi: 10.1136/vr.152.11.323

34. Wernham BG, Trumpatori B, Hash J, Lipsett J, Davidson G, Wackerow P, et al. Dose reduction of meloxicam in dogs with osteoarthritis-associated pain and impaired mobility. J Vet Intern Med. (2011) 25:1298-305. doi: 10.1111/j.1939-1676.2011.00825.x

35. Gruet P, Seewald W, King JN. Evaluation of subcutaneous and oral administration of robenacoxib and meloxicam for the treatment of acute pain and inflammation associated with orthopedic surgery in dogs. Am J Vet Res. (2011) 72:184-93. doi: 10.2460/ajvr.72.2.184

36. Kazakos GM, Papazoglou LG, Rallis T, Tsimopoulos G, Adamama-Moraitou $\mathrm{K}$, Tea A. Effects of meloxicam on the haemostatic profile of dogs undergoing orthopaedic surgery. Vet Rec. (2005) 157:444-6. doi: 10.1136/vr.157.15.444

37. Doig PA, Purbrick KA, Hare JE, McKeown DB. Clinical efficacy and tolerance of meloxicam in dogs with chronic osteoarthritis. Can Vet J. (2000) 41:296300

38. Hare JE, Niemuller CA, Petrick DM. Target animal safety study of meloxicam administered via transmucosal oral spray (Promist[(R)] technology) for 6 months in dogs. J Vet Pharmacol Therap. (2013) 36:412-6. doi: $10.1111 /$ jvp.12018

39. Bazelle J, Threlfall A, Whitley N. Gastroprotectants in small animal veterinary practice - a review of the evidence. Part 1: cyto-protective drugs. J Small Anim Pract. (2018) 59:587-602. doi: 10.1111/jsap.12867

Conflict of Interest Statement: The authors declare that the research was conducted in the absence of any commercial or financial relationships that could be construed as a potential conflict of interest.

Copyright (C) 2019 Rehbein, Manchi, Gruber and Kohn. This is an open-access article distributed under the terms of the Creative Commons Attribution License (CC BY). The use, distribution or reproduction in other forums is permitted, provided the original author(s) and the copyright owner(s) are credited and that the original publication in this journal is cited, in accordance with accepted academic practice. No use, distribution or reproduction is permitted which does not comply with these terms. 